\title{
Views towards the revolution history course of foreign students in Turkey
}

\author{
Zafer Tangülï̈ $^{1}$, Beytullah Kaya ${ }^{2}$ \\ ${ }^{1}$ Department of Social Studies Teaching, Faculty of Education, Mugla Sitki Kocman University, Turkey \\ ${ }^{2}$ Department of History, Humanities and Social Sciences, Sabahattin Zaim University, Turkey
}

\begin{tabular}{l}
\hline Article Info \\
\hline Article history: \\
Received Aug 10, 2018 \\
Revised Oct 25, 2018 \\
Accepted Dec 14, 2018 \\
\hline
\end{tabular}

Keywords:

Foreign students

Principles of atatürk and history

of the Turkish revolution course

Tertiary level

\begin{abstract}
Teaching of Principles of Atatürk and History of the Turkish Revolution course has a role in the realization of national goals in higher education. The universal messages the program contains clearly demonstrate that the course has also a universal role beside the national identity of it. The purpose of this study is to investigate the opinions of foreign students studying in Turkey towards Principles of Atatürk and History of the Turkish Revolution course. To this end, this research is a case study in the qualitative research design. There are 12 foreign students studying at Istanbul Sebahattin Zaim University participated in the study. The participants of the study were selected by purposive sampling method among criterion sampling methods. The criterion to pick these students was that they were accepted on the condition that they did Principles of Atatürk and History of the Turkish Revolution course for at least one semester at university. Semi-structured interview form with five questions was prepared in order to determine the opinions of students participating in the research and content analysis was utilized to analyze the data obtained from the research and discourse analysis methods were employed to present the data. Research findings show that students are of the opinion that the course is very necessary for them and that it helps them to get scholar knowledge on Turkish history and it also helps them to get accurate history knowledge.
\end{abstract}

Copyright (C) 2019 Institute of Advanced Engineering and Science. All rights reserved.

\section{Corresponding Author:}

Zafer Tangülü, Department of Elementary Education, Mugla Sitkı Kocman University, Kotekli, Mugla County 48000, Turkey.

Email: zafertangulu@gmail.com

\section{INTRODUCTION}

Schools known as planned formal education centers have two missions. Firstly, they pass the state's official ideology through their programs. Secondly, they transfer official state ideology of the schools to the citizens through implicit regulations and accordingly they create the ideal citizen type [1]. As an offspring of the Ottoman Empire, the new young Turkish Republic founded in Anatolia established itself on the principle of raising the appropriate individuals who are suited to education in general, and history education in particular, which is based on the principle of a nation state understanding and accordingly it shaped its education programs within this direction. Each state wants to create an ideology, its methods, its institutions, its principles and a new educational regime which can achieve its own goals. This means a new vision, understanding, behavior, way of life and form suitable for the purpose of this recent established state [2]. Deriving from its inherent dynamics, all education systems want to have a citizen model and while preparing their programs they base their expectations on this citizen type. This leads to the conclusion that all activities in educational institutions are aimed at a certain purpose [3]. 
Addressing the history course in accordance with gaining national identity consciousness and opening the official ideology of legitimacy path has undoubtedly made the topics of national history and the topics of Principles of Atatürk and History of the Turkish Revolution course both important and valuable from all stages of education starting from primary education to tertiary level education [4], [5]. The Principles of Ataturk and History of the Turkish Revolution course aims to have the young generation have a positive attitude towards the basic philosophy of the Turkish revolution in general and the Republican regime and the principles and reforms of Ataturk. Thus, the course qualified in introducing both contemporary society conditions and principles and ideals of democracy as well as showing how Republic of Turkey is influenced by the complex international relations and the difficulties it faces and the ways it utilizes in solving the difficulties it faces [6].

The teaching of the history of the newly established Republic was regarded as urgent and priority work. That is why, Principles of Atatürk and History of the Turkish Revolution course, which is attached great responsibility and mission, has held a significant place in teaching the younger generations the history of the Republic. In this regard, the course shedding light and leading the young generation to the right path aims to inform the Turkish youth, who are considered as a guarantee of the future, about the struggle against the great powers of the world, and how national independence and independence were achieved [7]. It is not only beneficial but also compulsory to consider Principles of Ataturk and History of the Turkish Revolution course as a dynamic cultural course which sheds light on Turkish youth and shows the right way [8].

History of the Revolution course was first given as "History of the Revolution" in 1925 by Mahmut Esat Bozkurt on and off on the axis of law and history at Ankara Law School [9]. The first course entitled as History of the Revolution was given at the Institute of Revolution on March 4, 1934, the day on which it was founded within the framework Istanbul University. The second course, on the other hand, was given at Ankara Law School by Ismet Inonu two weeks later [10]. During this period, the course was presented gradually in the form of lectures by statesmen like Mahmut Esat Bozkurt, Recep Peker, Yusuf Kemal Tengirşenk, Yusuf Hikmet Bayur and in this way the transmission of the values and virtues of the Turkish Republic as well as the strength of it were prioritized. Yusuf Kemal Tengirsenk expressed his view that the first objective while giving this course in his first lesson, he considered it as his duty to pass the enthusiasm onto the young who were supposed to safeguard and sustain the revolution [11]. From 1942 onwards, the course was left to the academicians at the universities with the establishment of the Institute of the History of Revolution and Republic of Turkey within the body of Ankara University. By 1968, the name of the course was changed by this institution as "History of the Turkish Revolution." Following the military coup on September 12, 1980, the name of the course was changed as "Principles of Atatürk and History of the Turkish Revolution." The preference of the word "inkılap" (a synonymous Turkish replacement word) instead of "revolution" (devrim) reveals that there is a return to the "original" concept as was used at the beginning [10]. In this regard, Kemalism and history of Turkish Republic holds a unique place in the approach towards the concept of modernisation. In addition, it is obvious that the following reasons played their role in the formation of this course.

Adopting the ideological organization of the newly established state at the end of the National Struggle for Turkish society, taking advantage of the History of the Revolution course in fulfilling the requirements of citizenship education, providing a comparative presentation of the History of the Revolution at international level, conveying the challenges faced by the regime to future generations and teaching them how to struggle with the difficulties they may face in the future [5], [12].

Recently, the development of technological facilities on a global scale along with transportation systems developing simultaneously have also accelerated various developments and changes in the education sector as it does in all other sectors. Quantitative and qualitative increases all around the world starting from primary education to tertiary level have both accelerated technical developments and transformed education into a force and prestige in interstate relations on a global scale. Our country has also been influenced by these changes and developments in recent years and it has become the center of attraction for a large number of foreign students thanks to its cultural wealth and historical background. Student mobility agreements made by Turkey at an international level and satisfying scholarship and accommodation facilities have made our country a center of attraction for foreign students. Within this respect, teaching of History of the Revolution and Kemalism course in higher education, which is the subject of this study, clearly shows that in the universal messages it contains although it plays a role mainly in the realization of national goals; thus, the course has a universal role besides its national identity. To this regard, the fact that the Turkish revolution has achieved an exemplary success among its precedents is not only national, but it also has made the fact necessary that this course should be internalized by foreign students as well as national ones and students should be able to derive implications for the future as the messages conveyed by this course are not only national, but universal. In the first lesson of the course, providing Turkish students with national and universal values is emphasized. However, the fact that the course is selected by foreign students and the fact

Int. J. Eval. \& Res. Educ. Vol. 8, No. 1, March 2019: 9 - 19 
that it is compulsory as well as other compulsory courses have led to the problem of how to give the course to foreign students. To this regard, no changes have been made in the course content or in the form the course is given to students. Today, many foreign students at various universities take this course together with Turkish students.

It has been reported by the Ministry of Internal Affairs and General Directorate of Immigration that within the 2016 Turkey Immigration under the heading of "foreigners" that the number of students studying in Turkey has reached to 795962 [13]. Over the past 10 years, the number of international students studying at our higher education institutions has increased by 75 percent. According to current figures, our country is one of the most internationally welcoming countries in the world, with approximately 110 thousand international students, 25 of whom are scholarship students.

All these figures are significant for our country in its political, cultural and social circles to determine the harmonization process of foreign students and at the same time to determine their views and opinions about our country [14].

\subsection{The purpose of the study}

The purpose of this study was to determine the views of the foreign students studying in Turkey towards Principles of Ataturk and History of the Revolution course. To this end, the sub-problems were investigated:

a. What do the foreign students studying in Turkey know about Turkey and the history of Turkey before taking Principles of Ataturk and History of the Revolution course?

b. How did taking Principles of Ataturk and History of the Revolution course affect the opinions of foreign students studying in Turkey about Republic of Turkey?

c. What are the perceptions of foreign students studying in Turkey about Ataturk before and after taking the Principles of Ataturk and History of the Revolution course?

d. What are the topics that foreign students studying in Turkey have difficulty in understanding while they are doing the Principles of Ataturk and History of the Revolution course?

e. What are the aspects that attract attention of foreign students studying in Turkey while they are doing the Principles of Ataturk and History of the Revolution course?

\section{RESEARCH METHOD}

This study is a case study in qualitative research design which aims to determine the views of foreign students studying Principles of Ataturk and the History of Turkish course in Turkey. Case studies are used to expose and describe the current situation within their own contexts [15]. Qualitative research methods were used since they allow the researcher to collect in-depth data [16], [17]. Besides, as the students' perceptions are to be revealed and that one of the prominent aims of qualitative research is to reveal perceptions of students, this method was exploited [18]. Data were collected through survey forms which are suited to the semi-structured interview technique.

\subsection{Study group}

12 students from different departments participated in the research at Sebahattin Zaim University in Istanbul. Criteria to participate in the research were selected by purposeful sampling method. The students were required to do Principles of Ataturk and the History of the Revolution Course at least one term and the prerequisite for the study was that they finished the English preparatory program. 6 female and 6 male students participated in the study. The fact that a separate class for foreign students was created for this course that made it possible that the study was conducted at this university.

\subsection{Data collection and analysis}

5-item semi-structured interview form was prepared in order to investigate the opinions of foreign students studying in Turkey. In order to secure internal validity, interview questions were examined by two experts in the field and in accordance with the views of the experts, special attention has been paid to issues such as the scope of the questions, their clarity, and their quality in targeting the required data. As a result, the experts arrived at the consensus that the interview form is applicable. The interview questions were piloted with two participants and the responses of the participants were analyzed.

Permission from Istanbul Sebahattin Zaim University was obtained to conduct the interview and the researcher provided each participant with the necessary information about the purpose of the study. It was ensured that the students were voluntary to take part in the research and they were reminded that they had the right to withdraw from the research whenever they wanted. During the study, the students were not manipulated by the researcher. The opinions of students were recorded with a tape recorder. 
Content analysis was utilized to analyze the data obtained from the research and discourse analysis methods were employed to present the data. The opinions of the participants were transcribed and similar responses were categorized under certain headings. The data were analyzed by the researcher and examined by an expert in the field. Following this, the data on which the expert arrived at a consensus were accepted and the others on which there were no consensus by the experts were discussed, revised and improved for use in the research. The statements of the students were summarized and presented in tables in such a way that the meaning and content integrity is not disrupted. Once the findings from interviews with students are made ready for use the students were interviewed again and asked if they wanted to state the same information as in the tables.

Since 11 students expressed that they wanted to state the same as the ones expressed in the table, the statements of the students were accepted as findings. As one of the participants stated that there was a difference between what she/he remarked, the data of her / his were not used. It is thought that such a result may have arisen due to the fact that these students had just learned Turkish at the time. In the study, the students whose data were collected were chosen from 10 different countries. Only two students from East Turkestan and one from other countries were included in the study. Considering the number of students that participated from Sebahattin Zaim University outnumbered others, two more students were included in the study.

\section{RESULTS AND DISCUSSION}

The results of the research were tabulated and presented in Table 1. When the table is analyzed, it can be observed that the majority of foreign students studying in Turkey generally come from Muslim countries. However, one student came from Germany. It is obvious that the students coming from other countries had either very little knowledge or knew nothing about Turkish history, the history of Ottoman Empire or the Republic of Turkey. Although the countries these students came from had associations politically, socially, financially or militarily with Turkish states, the Ottoman Empire or the Republic of Turkey, it seems that they do not allocate any of these subjects in their curricula.

Table 1. The opinions of foreign students studying in Turkey about their knowledge of Turkish history prior

\begin{tabular}{|c|c|}
\hline Country & Opinion \\
\hline Iran & $\begin{array}{l}\text { I did not know anything about Turkish history. The only thing I heard was Battle of Chaldiran. I had heard } \\
\text { nothing about Republic of Turkey or the agreements. }\end{array}$ \\
\hline Somaliland & $\begin{array}{c}\text { Nothing is mentioned about Turkish history in our country. I learnt by myself. The history of Ottoman } \\
\text { Empire was mentioned. They used to say that Ottoman Empire was colonial. They used to say very little } \\
\text { about World War I. }\end{array}$ \\
\hline Turkmenistan & $\begin{array}{l}\text { I did not know anything about Turkish history. Yet, I heard about Turkey. My father worked in Turkey } \\
\text { between 2003- } 2008 \text { and when he returned he started to teach me Turkish. Then, I thought I could go to } \\
\text { Turkey. In our country, the legend of Oghuz Khan and Korkut Ata are taught. They also used to teach us } \\
\text { and give some information about the Ottoman Empire. I had learnt that Ataturk contributed to Turkish } \\
\text { history in a positive way. }\end{array}$ \\
\hline Syria & $\begin{array}{l}\text { They do not tell us a lot about the Ottoman Empire. We only know about the relics from that period. } \\
\text { Simply, they told us that we went to World War. We were told what BesharEsad and his father had done in } \\
\text { our Kavmiyeclass at school. }\end{array}$ \\
\hline East Turkestan (1) & $\begin{array}{l}\text { I had heard Ataturk about Turkey. I used to believe that he founded a state at a time when the Ottoman } \\
\text { Empire was at a very good condition. But now I know that it was not true. In our country, the topic of } \\
\text { Turkey is forbidden. Nothing is told. }\end{array}$ \\
\hline East Turkestan (2) & $\begin{array}{l}\text { I did not have much information. My father had given me some information previously. He used to tell me } \\
\text { about Sultan Abdul Hamid II. They never teach anything at the schools. They make us forget the fact that } \\
\text { we are Turkish. }\end{array}$ \\
\hline Burkina Faso & $\begin{array}{l}\text { I know very little; I had heard about Ataturk but did not know what he had done. We only knew that he } \\
\text { abolished the caliph and oppressed the religious scholars. We learnt these at Turkish high schools. }\end{array}$ \\
\hline Mali & I studied at a Turkish high school and learnt very little about Turkish history. \\
\hline Tajikistan & $\begin{array}{l}\text { I had learnt about the Ottoman Empire before. I had studied at a private high school and learnt that in my } \\
\text { home country. }\end{array}$ \\
\hline Germany & $\begin{array}{l}\text { I nearly knew nothing about history. I studied German and European history. I never studied Turkish } \\
\text { history. Ottoman Empire takes place very shortly- in a paragraph- at the 8th and 9th grades in Germany. I } \\
\text { learnt here for the first time that Germany and the Ottoman Empire were allies in World War I. }\end{array}$ \\
\hline Yemen & $\begin{array}{l}\text { Nothing is told about Turkish history in our country. I did not have any information about Turkish history } \\
\text { and the history of Ottoman Empire before I came here. }\end{array}$ \\
\hline
\end{tabular}

Int. J. Eval. \& Res. Educ. Vol. 8, No. 1, March 2019: 9 - 19 
In the countries under Ottoman domination, the history of Ottoman Empire is never given or The Ottoman Empire is taught to students as an imperialist country. For instance, the student who was from Somaliland stated that the only information she/he learned was that the Ottoman Empire was a colonial power. In some other countries, on the other hand, Turkey is not given any place at all because of political reasons. Countries such as Syria and China do not allocate any content related to either Turkish history or the history of the Ottoman Empire in their syllabuses at their schools due to political reasons. In the interviews, although the students coming from Mali and Burkinafaso stated that they studied at Turkish high schools, they expressed the fact that they either had very little knowledge or had no knowledge at all. On the other hand, the student from Germany stated that there was merely a paragraph on the Ottoman Empire and Turkish history in their content. It is obvious from the interviews that the students from other countries had either very little information or they had no information concerning Turkish history, the Ottoman Empire or the Republic of Turkey. Table 2 describes the opinion of foreign students.

Table 2. The opinions of foreign students towards whether "Principles of Ataturk and History of the Turkish Revolution" course had any effect on their views about the Republic of Turkey

\begin{tabular}{|c|c|}
\hline Country & Opinion \\
\hline Iran & $\begin{array}{l}\text { I am a person who likes history. Now I am more interested in Turkish history. After taking this course, I } \\
\text { discovered that what other people said had some flaws. For example, I had heard negative things about } \\
\text { the Republican period. However, now I realize that these were to establish the Republic of Turkey. }\end{array}$ \\
\hline Somaliland & $\begin{array}{l}\text { I learned some information in these class. I got some new information concerning the establishment of the } \\
\text { Turkish state. I discovered the fact that some information I had known prior to taking this course was } \\
\text { misleading. }\end{array}$ \\
\hline Turkmenistan & $\begin{array}{l}\text { I do not know if this course has changed my views, but it has prepared me to learn new information. I } \\
\text { think there are some things that need to be done. }\end{array}$ \\
\hline Syria & $\begin{array}{l}\text { I learned the things that were done for World War I. I learned where our soldiers became martyrs. I } \\
\text { learned about Ataturk. I learned about Turkish history. }\end{array}$ \\
\hline East Turkestan (1) & $\begin{array}{l}\text { Previously I used to think that it would be better if the Ottoman Empire continued to exist. However, now } \\
\text { I understand that it is not as it seems and it was founded so as to halt the fact that the Ottoman Empire } \\
\text { was doing badly. }\end{array}$ \\
\hline East Turkestan (2) & $\begin{array}{l}\text { The course provided me with a basic framework. I came to know how the Ottoman Empire collapsed and } \\
\text { how much the west struggled in order to destroy the Ottoman Empire. I got information about the } \\
\text { establishment of the Republic of Turkey. }\end{array}$ \\
\hline Burkina Faso & $\begin{array}{c}\text { The Ottomans had a lot of problems. If he had not been for him (Mustafa Kemal) the country would not } \\
\text { have existed. He brought the country together. }\end{array}$ \\
\hline Mali & I learned about Turkish history. I came to understand that it holds a significant place in the world. \\
\hline Tajikistan & $\begin{array}{l}\text { I had some information about World war I, yet I did not know much about Ataturk. The things I know } \\
\text { about Ataturk is generally negative. My father and brother told me these. }\end{array}$ \\
\hline Germany & $\begin{array}{l}\text { There is a strict attitude in Turkey. I see that the things that happened as a result of a particular problem. } \\
\text { Thanks to this course, my views on historical events changed. And I became more interested in the events } \\
\text { taking place in the last century. }\end{array}$ \\
\hline Yemen & $\begin{array}{l}\text { In this course, I learned what the feeling of motherland means. In our case, the concepts of country, } \\
\text { people and flag are perceived differently. }\end{array}$ \\
\hline
\end{tabular}

The majority of foreign students stated that they had negative perceptions towards Republic of Turkey prior to doing this course. It is understood from the interviews that there exists a tendency to see the collapse of the Ottoman Empire as directly connected to Mustafa Kemal. Some of the students are of the opinion that Mustafa Kemal destroyed the Ottoman Empire in order to establish the Turkish Republic. Since students did not get enough information and since they received information through informal ways outside of the school, the information they have seems to be inaccurate. For this reason, it can be deduced that there exists a negative attitude towards Mustafa Kemal and the reforms he made. The findings derived from the interviews carried out with students from Iran, Somaliland and Tajikistan could be presented as an example. Besides, all students stated that they got some information about the Republic of Turkey and how it was founded.

The interviews done with students from Iran, Somaliland, East Turkistan and Mali were revealing in that the students expressed they corrected the inaccurate information they had previously known and they got information about the Republic of Turkey. Furthermore, some students stated that they took more interest in subjects in history thanks to this course. The remark of the student coming from Germany as "My point of view has changed thanks to this course. And I became more interested in the events that happened over the last century" can be presented as a finding which reveals this attitude. Another finding in the study is that there has developed an attitude in students to create the notion of a nation. The students who was from Yemen pointed out the fact that he got the feeling of motherland and the concepts like nation, and flag became more meaningful.

It can be understood from Table 3 that all foreign students had negative views about Ataturk prior to 
taking this course. The students had built a negative attitude because of the information they received from their surroundings as well as through misleading information or imperfect knowledge. The fact that the Ottoman Empire collapsed and the new republic was established plays a major role in students' having such a view. Some students have some inaccurate knowledge in terms of history that the Ottoman Empire collapsed by Mustafa Kemal without any reason.

Table 3. The opinions of foreign students about Mustafa Kemal before and after doing the course

\begin{tabular}{|c|c|}
\hline Country & Opinion \\
\hline Iran & $\begin{array}{l}\text { My opinions have changed. I used to criticize Ataturk before I took this course. He was already } \\
\text { considered negatively in the Islamic world. I used to think that the things he did were wrong and } \\
\text { he behaved like that since the English desired so; however, my view has changed now. I found } \\
\text { some of his actions wrong such as his abolition the caliphate. Ataturk did all these in order to } \\
\text { establish the state of the Republic of Turkey. }\end{array}$ \\
\hline \multirow[t]{2}{*}{ Somaliland } & $\begin{array}{l}\text { My thoughts about Ataturk were a bit distressing. I mean it was negative. I knew him as the } \\
\text { person who destroyed the Ottoman Empire. Every person has his mistakes as well as his good } \\
\text { sides. Ataturk brought Turkey independence. Turkey }\end{array}$ \\
\hline & $\begin{array}{c}\text { Turkey liberated, otherwise it was going to be a colony. I think the bad side was that he } \\
\text { established a little state out of a big one like the Ottoman Empire. }\end{array}$ \\
\hline Turkmenistan & My view about Ataturk has improved. He made these reforms as they were necessary. \\
\hline Syria & $\begin{array}{l}\text { I had known that he founded the Republic of Turkey. I learnt that he was excel at administrative } \\
\text { matters. Some people do not like his views in terms of his religious beliefs, yet the state is a great } \\
\text { achievement. I discovered that what I had previously known was not accurate. }\end{array}$ \\
\hline East & I learnt about the Ottoman Empire and Ataturk when I was in Egypt. They used to say there that \\
\hline Turkestan (1) & $\begin{array}{l}\text { Ataturk was against religion. Now I realize that some things had to be done since the Ottoman } \\
\text { Empire started to fall to pieces. My view about Ataturk has changed. } \\
\text { I believe that he acted so since it was necessary at the time. }\end{array}$ \\
\hline $\begin{array}{c}\text { East } \\
\text { Turkestan (2) }\end{array}$ & $\begin{array}{l}\text { I always heard negative things about Ataturk. The elderly in our country used to say that he } \\
\text { collapsed the Ottoman Empire and the Western states took advantage of him. After taking the } \\
\text { course, I came to realize that he founded a new state and tried to build a nation. He struggled with } \\
\text { the west. I think if it had not been for him, the Ottoman Empire could have continued to exist. }\end{array}$ \\
\hline Burkina Faso & $\begin{array}{l}\text { My opinion has now changed. It is possible for him not to be such a religious person but he can do } \\
\text { these things for the sake of his country. You can be a religious person but with no motherland, this } \\
\text { is also bad. I searched on the Internet that some people state that he is a religious person while } \\
\text { some other do not say so. That he removed the characters of the Koran and that he punished some } \\
\text { scholars is wrong in my opinion. }\end{array}$ \\
\hline Mali & $\begin{array}{l}\text { I did not hear anything about Ataturk before taking the course. However, I learnt from him that } \\
\text { you will never have your land unless you struggle. I became aware of the importance having a } \\
\text { state. }\end{array}$ \\
\hline Tajikistan & $\begin{array}{c}\text { My views concerning Mustafa Kemal have not changed. I mean I still have negative views about } \\
\text { him. }\end{array}$ \\
\hline Germany & There have been some changes in my previous knowledge, not many though. \\
\hline & $\begin{array}{l}\text { Now I can understand better why the things that were done during the Republican period were } \\
\text { done. I think some of them are good whereas others are unnecessary }\end{array}$ \\
\hline Yemen & $\begin{array}{l}\text { I had a negative view about Mustafa Kemal. In general, all the knowledge I had about him was } \\
\text { from my family environment and friends. I thought that some of his endeavors were negative in } \\
\text { terms of religion. Now, however, I appreciate his struggles to save his country. }\end{array}$ \\
\hline
\end{tabular}

Moreover, some students have such an opinion of Mustafa Kemal by deriving from his reforms that he did these against Islam. The abolition of the caliphate and the alphabet reform in particular seem to be effective in the occurrence of this negative view among students. The student from Iran stated that Mustafa Kemal is regarded negatively and exemplified the abolition of the caliphate for this. It is understood that the students are highly influenced from religious references in formation of their negative perceptions. What is more, the students expressed that they learned this information from the elderly or the people in the surroundings in their countries. This increases the possibility of the existence of such a perception. For example, the students from Yemen and East Turkestan stated that they learned these from the elderly in their countries with this question. Moreover, the students responded similarly to the other questions.

One of the students stated that her/his opinions changed after taking the course. The students from Tajikistan, on the other hand, stated that her/his views remained the same. Other students started to address historical events with their new learning experiences in a more academic way. The students stated that the reason why a new state was established derived from the fact that the new state required new institutions; therefore, some reforms were done. The student from East Tajikistan (1) expressed his view that the reforms at that period were done as they were necessary.

The students from Iran and Somali stated that the things he (Mustafa Kemal Ataturk) did was to establish a new state. It can be stipulated that their views changed as they improved themselves academically. 
It is obvious from Table 4 that foreign students have difficulty in understanding a concept in a foreign language as well as interpreting it and attributing a meaning to it. When the students were asked which topics they found difficult most, 5 students stated that they found it difficult to learn the concepts forthright. These students pointed out that they had difficulty in learning the meaning in Turkish terminology as well as the concepts existing in the history of revolution course. Besides, the rest of the students stated that they had difficulty in learning the topics like agreements, wars, important dates and the congresses taking place within World War I.

Table 4. The opinions of foreign students about the topics they have difficulty understanding in "Principles of

\begin{tabular}{|c|c|}
\hline Country & Opinion \\
\hline Iran & The subject I found difficult was to learn the agreements and memorize them. \\
\hline Somaliland & I have difficulty in learning the topics and concepts that require memorization. \\
\hline Turkmenistan & $\begin{array}{l}\text { I had difficulty while I was learning the concepts in the first term. It was } \\
\text { difficult to learn periods of war and the agreements. }\end{array}$ \\
\hline Syria & It was rather difficult to learn the concepts of the first term. \\
\hline East Turkestan (1) & $\begin{array}{l}\text { I had difficulty in learning the wars during the first term. The wars and the } \\
\text { agreements were a bit complicated. }\end{array}$ \\
\hline East Turkestan (2) & It was rather difficult to learn the concepts. \\
\hline Burkina Faso & I no more have difficulty. I had difficulty in the dates in the first term. \\
\hline Mali & I have difficulty in understanding the terminology and the concepts. \\
\hline Tajikistan & I had difficulty about the congresses. It is rather a difficult subject to learn. \\
\hline Germany & $\begin{array}{l}\text { It is difficult for me to learn the theoretical knowledge within history. It feels a } \\
\text { bit difficult to learn about World War I. }\end{array}$ \\
\hline Yemen & I had great difficulty in learning the concepts within the course syllabus. \\
\hline
\end{tabular}

When students are asked what subjects they are interested in, the Iranian student stated that s/he is interested in Ataturk and the people who were involved in the history of the Ottoman Empire. The student from Somali pointed out that $\mathrm{s} / \mathrm{he}$ is interested in the topics which are lectured like storytelling. The students from Turkmenistan and East Turkestan (1) stated that they are interested in the way the reforms were done during the Republican period whereas the Syrian and Malian students were interested in the lives of the Ottoman emperors. Moreover, the student from Tajikistan was interested in the topics of World War I, the German student was into the topics of the Ottoman Empire and Turkey and finally the Yemeni student was interested in the ways how a state should be governed. The issues that attract the attention of a large majority of students seem to be related to the reforms made in the process of state establishment and management.

By deriving from the speeches of the students, it can be suggested that the students are eager to learn and take these developments and events happening at this period as a model for their home countries. For example, the speeches of students from Turkmenistan, East Turkestan, Mali and Yemen can be shown as an example for this. When students are asked to give their views concerning the offering of this course for foreign students, they stated that it should be offered in order for foreign students to get information about Turkish history and recognize Turkey correctly. Through this lesson, the students expressed that they learned the right information about the country they are visiting. Table 5 reveals opinions of foreign students about the topics they are interested in in "Principles of Atatürk and History of the Turkish Revolution" course and the reasons for their interest.

What is more, it is obvious that the knowledge of students in terms of Turkish history is limited as these subjects do not take place in Iranian lessons despite many political events that took place between the Ottoman-Iran and between Iran and the Republic of Turkey. With regard to this sub-problem, it seems that the information of the participants on Turkish history and culture is very limited before taking lessons in general. It can be claimed that the history programs in the students' countries are particularly shaped by its political institutions. The striking point here is that the students neither have knowledge with regard to the Ottoman Empire nor the Republican history despite the many relics that emerged from the Ottoman hegemony and still continued to exist until this day. 
Table 5. Opinions of foreign students about the topics they are interested in in "Principles of Atatürk and History of the Turkish Revolution" course and the reasons for their interest

\begin{tabular}{|c|c|}
\hline Country & Opinion \\
\hline Iran & $\begin{array}{l}\text { Now I like learning about Ataturk and the Ottoman Empire. I like learning about } \\
\text { the people in history through storytelling. I think there is a need for this course. I } \\
\text { mean if we some to this country, we need to be informed about the history of it. I } \\
\text { think we need to learn the Ottoman Empire as well. Because it is our past. }\end{array}$ \\
\hline Somaliland & $\begin{array}{l}\text { I like the course being lectured with stories. I think foreign students need to learn } \\
\text { this. If one lives within a country, it is necessary to learn its history and culture. I } \\
\text { hope what I have learned so far will be helpful for me in the future. }\end{array}$ \\
\hline Turkmenistan & $\begin{array}{l}\text { The reforms that were done during the establishment of the Republic attracts my } \\
\text { attention. The fact that there were examples on how we could do reforms in our } \\
\text { home country in the future. I think there is a must for this course to be given for } \\
\text { foreign students. Because it contributes to our learning about the history of the } \\
\text { country that we come from. }\end{array}$ \\
\hline Syria & $\begin{array}{l}\text { I like learning about the Ottoman sultans and their lives. In my opinion, this } \\
\text { course is important and I am of the opinion that it should be offered to foreign } \\
\text { students. }\end{array}$ \\
\hline East & I am interested in the reforms done during the establishment period of the \\
\hline Turkestan (1) & $\begin{array}{l}\text { Republic of Turkey. Learning things we should pay attention to if we have a state } \\
\text { in the future makes me happy. I like learning about the procedures in building a } \\
\text { state. In my opinion, this course should be offered to every foreign student. } \\
\text { Because I got some interesting information about the ottoman Empire and the } \\
\text { Republican era. }\end{array}$ \\
\hline $\begin{array}{c}\text { East } \\
\text { Turkestan (2) }\end{array}$ & $\begin{array}{l}\text { We gain some general knowledge in the course, and for this reason it is a decent } \\
\text { course, in my view. I think there must be a course like this and foreign students } \\
\text { should get information about Turkey. }\end{array}$ \\
\hline Burkina Faso & $\begin{array}{l}\text { I like the course in general. In my view, this course shoul be offered to foreign } \\
\text { students. If we live in this country, we need to know what is happening in our } \\
\text { country and learn a lesson from these. Also, we should do these in our home } \\
\text { country. This course is an opportunity to get to know Turkey and that is why it } \\
\text { should be offered. }\end{array}$ \\
\hline Mali & $\begin{array}{l}\text { I like historical stories. I am interested in the fact that true events take place in the } \\
\text { course of past events. In my opinion, this course should definitely be offered to } \\
\text { foreign students. Because it guides us and gives us the feeling that it is necessary } \\
\text { to struggle to establish a state. }\end{array}$ \\
\hline Tajikistan & $\begin{array}{l}\text { I am interested in World War matters. I find them easy as I learned them before. I } \\
\text { think this course should be offered to foreign students. }\end{array}$ \\
\hline Germany & $\begin{array}{l}\text { I am more interested in the subjects of the Ottoman Empire and Turkey. I am } \\
\text { curious about these topics. In my opinion, it is a significant course for foreign } \\
\text { students to get to know Turkey. }\end{array}$ \\
\hline Yemen & $\begin{array}{l}\text { It is interesting to learn the information about how a state should be governed. } \\
\text { Such matters attracted my attention more in this course. The process of Mustafa } \\
\text { Kemal's establishing the new state attracted my attention. I think it is good that } \\
\text { this course is offered. It is good to learn about the country where we are hosted. }\end{array}$ \\
\hline
\end{tabular}

All participants responded appropriately to the question directed to the them in accordance with the second sub-problem as 'How did taking Principles of Ataturk and History of the Revolution course affect your opinions about Republic of Turkey?' with soundreasons. Thanks to this course, the participants stated that they corrected the misleading information they had had previously and freed themselves from prejudices. On the basis of these false information and prejudices, the process of the National Struggle initiated under the leadership of Atatürk lies in the process of the collapse of the Ottoman State. Before the participants did this course, they maintained that this process seemed unnecessary or they thought it was even a rebellious attitude against the Ottoman Empire. After doing this course, the students regarded the national struggle period as an attempt to justify their land against the imperialist forces after the Ottomans and they appreciated the reasons of this process and developed their point of view in a way that promised the continuity in the process from the Ottomans to the Republic in Turkish history. This finding is in accordance with the objective of offering this course at higher education.

In the related legislation of the course, the statement as The purpose of the Principles of Ataturk and History of the Turkish Revolution is to explain the circumstances under which The Republic of Turkey was established and make them internalize the Kemalist thought, its philosophy, principles and contemporary values is incompatible with this purpose and finding. Another striking response in line with this sub-problem was given by the Yemeni student. The participant pointed out that thanks to this course some notions such as nation and flag are ascribed meaning and emphasized to a high extent with a nationalist understanding; thus, $\mathrm{s} /$ he contended that this notion is highly different from the perceptions from their home country. Arsal also stated that values and skills within the course content are transferred with a nationalistic understanding and 
he stressed the need for the transmission of values and skills in this way [21]. In the historical events conveyed within the framework of this course it is emphasized that the republic of Turkey is founded on nationalism. It is indicated by the findings that the students had negative attitudes towards the process of the establishment of the Republic of Turkey before taking the course. The reason for this negative attitudes derives either from their elderly in their home countries or the knowledge they learnt in an informal way upon their arrival in Turkey.

The participants were asked the question 'What are the perceptions of foreign students studying in Turkey about Ataturk before and after taking the Principles of Ataturk and History of the Revolution course?' in accordance with the third sub-problem of the research. It is obvious that apart from the student who was from Tajikistan, all other participants responded to this question in a way that their perception of Ataturk changed after taking this course. In general, before taking this course the participants reached a consensus that national struggle initiated by Atatürk was against the Ottomans; thus, to the caliphate and that the process continued against the religious bases. However, upon taking the course they arrived at a consensus that the things that were done were against imperialist occupying states so as to secure both political and religious values. The responses, particularly the ones given by the participants coming from the African continent that were the previous colonies of the European countries are striking in that they tend to emphasize the fact that Ataturk rescued the country from being colonized by establishing the new Republican state thanks to the National Struggle. It can be understood that the participants had difficulty in admitting the new Republic of Turkey, which fitted into a smaller geographical location compared to the Ottoman, which had a wide range of Islamic geographical dominance. However, they came to an agreement that this was a process under the leadership of Ataturk, which was, in fact, a compulsory transmission and continuity for the new state.However, one thing is certain that historical processes cannot be evaluated independently of their period. In his study, Y1lmaz stressed out although the Ottoman Empire deserves a more objective criticism it is still common to realize the mentality which is either all rejectionist or admissive [22].

The participants were asked the question in accordance with the fourth sub-problem of the study 'What were the topics they had difficulty in understanding while they were doing the Principles of Ataturk and History of the Revolution course?' The participants reached a consensus that they mainly had difficulty in the topics like World War I,chronology of historical events, agreements etc., which require memorization. In his study, Akbaba stressed out the need for the use of different teaching methods rather than direct instruction technique in order for Principles of Ataturk and the History of Turkish Revolution course to be sustained in a way to serve its purpose as intended [23]. Thus, in a way, he pointed out the need for students to be freed from memorization.

On the other hand, the participants found the new notions very difficult. For the ones taking this course for the first time, the notions like principle, revolution, reform and Kemalism etc. could be difficult to learn or internalize. If the students cannot accommodate these new concepts in their minds, some misconceptions might occur. Demircioğlu, Ulusoy, and Kaymakç1 focused on the teaching of history in general, and Revolution History and Kemalism in particular, and concluded that their students were mistaken about some concepts [24]-[26]. As a result of these findings, they made some suggestions so as to ensure a better and effective teaching process. In the study he carried out with Turkish students, Kaya concluded that the students had difficulty in learning the historical concepts [27]. Kaya suggests visualization and lecturing through storytelling while the concepts are taught to students. Karabag pointed out that the teaching of concepts is neglected and that students particularly have difficulty while they are trying to make sense and learn the abstract concepts [28]. All these taken into consideration, even when the research is conducted with Turkish students, the result remains the same. Thus, it could be concluded that it is very natural for foreign students to have some learning difficulties and difficulties in memorizing and learning the specific events and concepts related to history in general and Revolution History and Kemalism course in particular. For this reason, teaching this course in a way that is free of memorization, getting out of the routines and making this course more than the chunks of information are important to teach foreign students in particular. The teaching staff should be able to make connections between the information in the textbooks and the real life and also take this learning process into non-school environments so that students can keep learning. Doğaner also reached similar findings and made similar suggestions and additionally he suggested the use of achievement tests at different intervals in order to enhance the quality and quantity of the learning process at higher institutions [29].

In accordance with the fifth sub-problem of the study, the participants were asked the question 'What are the aspects that attract attention of foreign students studying in Turkey while they are doing the Principles of Ataturk and History of the Revolution course?' When the responses to this question is analyzed, all students are interested in the topics of this course in general. The rationale for this derives from the fact that all students are of the opinion that it is a necessity to learn the historical events and the background of a country rather than considering it as a subject which is fun and which arouses curiosity. The 
most striking answer among the responses of the participants is by the students from Tajikistan as "The reforms that are made for the establishment of the Republic arouses my attention. It makes me happy to learn what we need to pay attention if we have an independent state in the future. I like learning about the things that need to be dome while establishing a state' is remarkable. In fact, it is palpable that the people of East Turkestan who struggled for independence for many years longs for an independent state and it takes the Republic of Turkey as a role model. To this question, the participants state that the reason why they are interested in these subjects in general derives from the fact that they are told as stories. It is overt that the use of different methods and techniques in general and the use of literary works in particular arouse the interest of students. Cencen concluded in a study he carried out that the Revolution History and Kemalism course which is supplemented with literary works fosters the curiosity, interest and the participation of the students [30]. With the answer to this final sub-problem, the participants maintained the necessity of this course and they also stated that doing this course made them happy. Students emphasized the importance of learning the history of the host country. What is more, the fact that students are happy as they are doing the course and that the majority of them find these subjects valuable and important complies with the findings of Doyran and Doyran's research [31].

\section{CONCLUSION}

Foreign students studying in Turkey, before arriving in Turkey and the Republic of Turkey made about Turkish history that they have limited knowledge are among the key results of the study. It can be concluded that this limited knowledge of students also includes misconceptions and inaccuracies. Students' knowledge gained from the tools such as social media or internet contributed to the emergence of this result. In addition, foreign students they have Atatürk'le wrong and incorrect information about the course before seeing the history of the revolution in Turkey, thanks to the knowledge they gained from academic sources have stated that they correct the course as a result of incorrect information. In addition, it is understood from the results of the study that the historical information that some students have learned in schools in their own countries, because they are historical information that is designed according to European or national interests, has academic errors.

Learning the concepts in history courses and discovering the meanings they contain contain various difficulties. In this study, it is concluded that students have difficulty in learning historical concepts. In addition, it was determined that the students had difficulty in learning the historical issues filled with political events and complex historical events. Interesting events in the history and anecdotes support the students' easy learning and positive attitude towards the course.

As a result of the study it could be suggested that the courses which involve the information about the countries which these students are hosted should be included in the curricula of these countries so as to raise the awareness of these students about the values and history of the countries where they are hosted. In addition, it is obvious that the prolongation of the lecturing of Principles of Ataturk and the History of Revolution course at higher institutions plays a role in establishing a bond between these students and Turkey. Thus, it could be suggested that this course should be sustained.

\section{REFERENCES}

[1] Dilek D, “Tarih Derslerinde Öğrenmeve Düşünce Gelişimi,” (3. Bask1), Ankara: Nobel Publishing, 2007.

[2] Akbaba B, "Atatürk İlkelerive İnkılap Tarihi Öğretiminde Çoklu Ortam Kullanımının Akademik Başarıve Tutumlara Etkisi," (Unpublished PhD Thesis), Gazi University, the Institute of Educatonal Sciences, Ankara, 2009.

[3] Kalkan HK, "Almanya'dave Türkiye'de Ortaöğretimde Okutulan Ders Kitaplarına Edebiyat Didaktiği Açısından Bir Yaklaşım," (Unpublished PhD Thesis), Ankara Uiversity Social Sciences Institute, Ankara, 2016.

[4] Emiroglu G, "Illköğretimde Türkiye Cumhuriyeti Inkllâp Tarihive Atatürkçülük Ders Konularının Öğretimi Üzerine Bir Araştırma," (Unpublished PhD Thesis), Selcuk University, Social Sciences Institute, Konya, 2002.

[5] Tangulu Z, "8.Sınıf Türkiye Cumhuriyeti İkılap Tarihive Atatürkçülük Dersinde Gazete Kullanımıve Buna Iliskin Ŏgretmen Gorusleri," (Unpublished Master Thesis), Gazi University The Institute of Educational Sciences, Ankara. 2011.

[6] Safran M, "Ĕgitim Bilimi Açısından Ataturk Ilkelerive Inkılâp Tarihi Ŏgretimi. Ataturk Ilkelerive Inkılâp Tarihinde Yontem Arayışları," Yediyıldız B, et al., (Eds.), "Hacettepe University Principles of Ataturk ve and the Institute of Revolution History Publishing," Ankara, 2004.

[7] Aksoy I, "Yüksek Öğretim Kurumlarında İnkılâp Tarihive Öğretimi," (Unpublished PhD Thesis), Gazi University, the Institute of Educatonal Sciences, Ankara, 2003.

[8] Cihan E, “Atatürk İlkelerive Inkılâp Tarihinde Etkin Eğitim Sorunları,” I. Atatürk İlkelerive İnkılâp Tarihi Semineri. Ondokuz Mayıs Üniversitesi Publishing.Samsun, 1985.

[9] Ozucetin Y and Nadar S, "Atatürk İlkelerive İnkılap Tarihi Dersinin Üniversiteler Düzeyinde Okutulmaya Başlanmasıve Gelinen Süreç,” Uluslararası Sosyal Araştırmalar Dergisi, 3/11, 2010.

Int. J. Eval. \& Res. Educ. Vol. 8, No. 1, March 2019: 9 - 19 
[10] Inan S, “Türkiye'deki Üniversitelerde İnkılâp Dersleri: Tarihsel Bakış,” Yükseköğretim Dergisi, vol. 2(1), pp. 55-58, 2012.

[11] Aslanapa O, “ílk Inkılâp Tarihi Ders Notları,” Türk Dünyası Araştırmaları Vakfı Publishing, İstanbul, 1997.

[12] Donmez C. and Yazıcı K, "T.C. Inkılâp Tarihive Atatürkçülük Konularının Öğretimi," Nobel Publishing, Ankara, 2008.

[13] [Online] Available from: https://www.ntv.com.tr/egitim/turkiyedeki-yabanci-ogrenci-sayisi-795-bin-962ye ulasti,OpnWuWDZLkyNsTNv5cZTpg (Retrieved on 26.03.2018).

[14] [Online] Available from: https://www.ytb.gov.tr/index.php/uluslararasi-ogrenciler/uluslararasi-ogrenci-hareketliligi, Retrieved on 04.04.2018.

[15] Yin KR, "Case Study Research Design and Methods," (fourth edition), SAGE Publications, California, 2009.

[16] Karasar N, “Bilimsel Araştırma Yöntemi,” (11. Print) Nobel, Ankara, 2002.

[17] Miles MB and Huberman AM, “Qualitative Data Analysis,” Sage, London, 1994.

[18] Yıldırım A and Şimşek H, "Sosyal Bilimlerde Nitel Araştırma Yöntemleri," Seçkin, Ankara, 2005.

[19] Oztas S, "Tarih Derslerinde Bir Öğretim Materyali: Edebî Ürünler," Rumeli'de Dilve Edebiyat Araştırmaları Dergisi, pp. 27-41, 2018.

[20] Ibret U, et.-al., "Sosyal Bilgiler Öğretmenlerinin Görüşlerine Göre Değerlerin Öğretiminde Edebi Ürünlerin Kullanımı,"Internatıonal Journal of Turkish Educatıon Sclences, vol. 5 (9), pp. 104-124, 2017.

[21] Arsal Z, "Ortaöğretim Tarih, Türkiye Cumhuriyeti İnkılâp Tarihive Atatürkçülük Dersleri Öğretim Programlarında Milliyetçilik," Sakarya University Education Faculty Journal, vol. 30, pp. 1-16, 2015.

[22] Yılmaz A, "İlköğretim 6, 7 ve 8. Sınıf Öğrencilerinde Osmanlı Algıs1," Atatürk Üniversitesi Sosyal Bilimler Enstitüsü Dergisi, vol. 12(2), pp. 245-261, 2008.

[23] Akbaba B, "Atatürk İlkeleri Ve İnkılâp Tarihi Dersinin Öğretiminde Karşılaşılan Sorunlar, A Gazi University Case," Gazi Akademik Bakış, vol. 1(2), pp. 177-197, 2008.

[24] Demircioğlu IH, "Sekizinci Sınıf Öğrencilerinin Tarih Öğretiminde Kullanılan Zaman ve Kronolojiyle İlgili Bazı Kavramları Anlama Düzeyi,” Eğitim Araştırmaları Dergisi, vol. 19, pp. 155-163, 2005.

[25] Ulusoy K and Yanpar-Yelken T, "İlköğretim 4. Ve 5. Sınıf Öğrencilerinin Atatürkçülükile İlgili Kavramları Algilamaları,” Sosyal Bilimler Dergisi, vol. 18, pp. 214-223, 2009.

[26] Kaymakçı S, "Sosyal Bilgiler Öğretmen Adaylarının İnkılâp Tarihi Öğretiminde Kullanılan Bazı Kavramları Anlama Düzeyi," Sosyal Bilimler Araştırmaları Dergisi, vol. 7(1), pp. 190-207, 2012.

[27] Kaya B, "The Effects of the Visualized and Fictionalized Concepts on Permanence and the Attitude of the Students in Revolution History of Turkish Repuclic and Kemalism courses,"Pensee Journal, vol. 6(10), pp. 235-247, 2014.

[28] Karabag G, “Türkiye'de Tarih Eğitimi Araştırmalarında, Kavram Öğretimi,” İH. Demircioğlu \& E. Demircioğlu (Ed.), In Türkiye'de Tarih Eğitimi Araştırmaları El Kitabı, Pegem Akademi, Ankara, pp. 229-258, 2017.

[29] Doğaner Y, "Yükseköğretimdeeğitimveöğretimelemaniyetiştirmesorunu, türkeğitimsisteminde Atatürkçülükve Cumhuriyet Tarihi Öğretimi,” Ankara: Hacettepe University Pub, pp. 181-196, 2006.

[30] Cencen N, "11. Sınıf Türkiye Cumhuriyeti İnkılâp Tarihive Atatürkçülük Dersinde Tarih Öğretmenlerinin "Edebi Ürün” Kullanımına İlişkin Görüşleri,” (Unpublished PhD Thesis) Gazi University, the Institute of Educational Sciences, Ankara, 2011.

[31] Doyran F and Doyran M, "Atatürk Ilkeleri Ve Inkılap Tarihi Dersi Zorunlu Ders Olmalı Mı? Üniversite Öğrencilerinin Görüşve Önerileri,"Turkish Studies - International Periodical for the Languages, Literature and History of Turkish or Turkic, vol. 8/3, pp. 163-177, Ankara, 2013.

\section{BIOGRAPHIES OF AUTHORS}

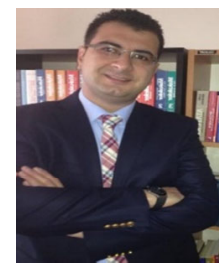

Assoc. Prof. Dr. Zafer Tangülü is completed his BA Degree at Frrat University, Faculty of Education, Social Studies Teaching Department and completed his MA Degree at Firat University on the same program. He took his PhD Degrees at Gazi University, Elementary Education Program. His research interests are social studies teaching teacher training, history education, effective history teaching, history, historical thinking skills.

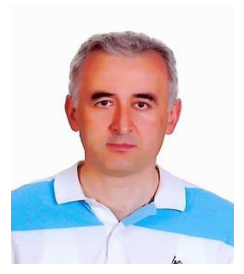

Assoc. Prof. Dr. Beytullah Kaya completed his BA. Degree at Karadeniz Teknik University, Faculty of Fatih Education, Department of History Teaching and completed his MA. Degree at Karadeniz Teknik University on the same program. Mr. Kaya took his PhD Degree at Marmara University, Department of Social Studies Teaching. His research interests are social studies teaching, teacher training, history of education, history, education of history and history of Turkish Republic. 